\title{
Effect of Thymus vulgaris leaf extract on cadmium-induced testicular toxicity in rats
}

\author{
Remigius Ibe Onoja ${ }^{1 *} \mathbb{D}$, Chinwe Uzoma Chukwudi ${ }^{1}$ Emmanuel Uchechukwu Ugwueze', \\ Davinson Chuka Anyogu', Wilson Obidah² and Benjamin Ifechukwu Emesiani ${ }^{3}$
}

\begin{abstract}
Background: Cadmium (Cd) is a known metallohormone which mimics the action of steroid hormones with adverse effect on testicular function. It is highly toxic and a prevalent environmental contaminant with no conventional antidote. This study investigates the possible ameliorative effects of Thymus vulgaris extract on testicular toxicity induced by $\mathrm{Cd}$ in male rats.
\end{abstract}

Results: The testicular and epididymal weights, serum concentration of follicle stimulating hormone, luteinizing hormone, and testosterone were significantly $(p \leq 0.05)$ lower in the cadmium-treated group compared to the control. Necrosis of germ cells of the seminiferous tubules was observed in the testicular tissues of the cadmiumtreated group. Administration of extract showed mild but non-significant $(p \geq 0.05)$ protective effect on the cadmiuminduced decrease in sex hormones and sperm count as well as oxidative stress and histological changes.

Conclusion: Thymus vulgaris leaf extract had weak ameliorative effect on cadmium-induced testicular injury in rats but with promising antioxidant activity.

Keywords: Cadmium, Rat, Testis, Thymus vulgaris, Toxicity

\section{Background}

Cadmium $(\mathrm{Cd})$ is a highly toxic environmental contaminant resulting from industrial activities. It is a heavy metal which is broadly utilized in industry but adversely affects animal and human health through occupational exposure, contaminated food and water or smoking (ElDemerdash et al. 2004; de Souza et al. 2010). This toxic metal enters and accumulates in different organs of the body in animals and man to cause severe tissue damage ranging from cellular degeneration, inflammation to cancers. Some of these organs include the kidney, liver, testicles, pancreas, thyroid, salivary glands, bone and brain (Thompson and Bannigan 2008; Ognjanović et al. 2010). However, the primary target organ for cadmium toxicity is the male reproductive organ. In the testes, a single

\footnotetext{
*Correspondence: remigius.onoja@unn.edu.ng

${ }^{1}$ Department of Veterinary Pathology and Microbiology, Faculty

of Veterinary Medicine, University of Nigeria, Nsukka 410001, Nigeria

Full list of author information is available at the end of the article
}

non-carcinogenic dose of $\mathrm{Cd}$ is known to cause significant testicular atrophy and calcification following bloodtestis barrier disruption, inflammation, germ cell loss and haemorrhage (Acharya et al. 2008; Ola-Mudathir et al. 2008; Deng et al. 2010). Previous reports have associated the toxic effects of $\mathrm{Cd}$ to its induction of oxidative stress and alteration in the antioxidant defence system in several tissues leading to a decrease in the activity of antioxidant enzymes and a change in cell membrane structure through lipid peroxidation (Bagchi et al. 1997; Zikic et al. 1998; Siu et al. 2009). This testicular oxidative stress and its associated cellular damage have been established as a major cause of severe male infertility due to $\mathrm{Cd}$ toxicity (Tremellen 2008; Turner and Lysiak 2008). Thus, heavy metal poisonings like $\mathrm{Cd}$ toxicity are suspected to be one of the major reasons for the recent declining fertility associated with reduced sperm count and testicular function in men in developed countries (Siu et al. 2009), as animals and humans that inhabit industrial areas where $\mathrm{Cd}$ is used for manufacturing certain products are 
vulnerable to accidental $\mathrm{Cd}$ exposure. However, modern research has shown that phytogenic compounds or bioactive compounds of plant origin are rich in antioxidants, such as flavonoids, phenols, terpenes, polysaccharides, saponins, alkaloids, vitamins, and trace elements (Miliauskas et al. 2004; Gouthamchandra et al. 2010; Chaves et al. 2020). These antioxidants directly or indirectly exert their effects on the body's antioxidant system by eliminating excessive free radicals and thus protecting the body (Chaves et al. 2020). Thymus vulgaris L. (Lamiaceae) is an indigenous perennial herb in Africa, Asia, central and southern Europe, that is known to be rich in essential oils and phenolic substances (WHO 1999). In folk medicine, it is widely used for the treatment of diseases such as gastroenteric and bronchopulmonary disorders and as an anthelmintic (Rustaiyan et al. 2000). It is also known to have immunomodulatory, anti-inflammatory, antioxidant and free radical scavenging effects (Vigo et al. 2004; El-Nekeety et al. 2011). It contains potent antioxidants such as carvacrol, linalool and thymol (Satyal et al. 2016). Therefore, this study was designed to evaluate the effect of Thymus vulgaris extract (TVE) on cadmium-induced testicular toxicity using male albino rats as they are genetically similar to human.

\section{Methods}

\section{Chemicals}

Cadmium chloride $\left(\mathrm{CdCl}_{2}-99 \%\right)$ was obtained from Sigma Aldrich Chemicals Co. (St. Louis, Mo, USA). All chemicals and reagents utilized were obtained from commercial suppliers.

\section{Extraction of plant material}

The leaves of T. vulgaris were purchased from Ogige market in Nsukka and identified by Mr. A. Ozioko, a botanist at the Department of Plant Science and Biotechnology, University of Nigeria, Nsukka, and the voucher specimen was deposited at the University of Nigeria Herbarium museum, with herbarium number UNNH648. The plant material was dried under shade for 10 days and ground to powder using a grinding machine. The powdered material was soaked in $70 \%$ methanol for 3 days after which it was filtered through Whatman paper (No. 1) and concentrated using a rotary evaporator (Daud et al. 2017). The T. vulgaris extract (TVE) obtained was stored at $4{ }^{\circ} \mathrm{C}$ and dissolved in $2 \%$ tween 80 in distilled water prior to administration (Onoja et al. 2020).

\section{Acute toxicity (LD50) study}

Acute toxicity (LD50) of the TVE extract was determined according to the Organization of Economic Cooperation and Development (OECD) guideline 423 (OECD 2003). Adult male rats were administered 625, 1250, 2500, and
$5000 \mathrm{mg} / \mathrm{kg}$ doses of the extract orally and observed for clinical signs of toxicity and mortality. No mortality or signs of toxicity were observed in animals administered $5000 \mathrm{mg} / \mathrm{kg}$ of the extract. Hence, the median lethal dose (LD50) was considered to be greater than $5000 \mathrm{mg} / \mathrm{kg}$ body weight in rats.

\section{Animals}

Thirty two healthy male albino rats about 10-12 weeks old, weighing between 160 and $180 \mathrm{~g}$ were obtained from the Experimental Animal Unit of the Zoological Garden, University of Nigeria, Nsukka. They were housed in standard metal cages with wood shavings as bedding in the Experimental Animal Unit of the Faculty of Veterinary Medicine, University of Nigeria, Nsukka and housed at a temperature of $25 \pm 4{ }^{\circ} \mathrm{C}$ and relative humidity of $65 \pm 5 \%$ with an alternating $12 \mathrm{~h}$ light and dark cycle. The animals had free access to food and water daily, and were acclimatized for one week before the commencement of the study.

\section{Experimental design}

The experiment was conducted in compliance with the National Institutes of Health guidelines on the care and use of laboratory animals (National Research Council 2011) as approved by the Faculty of Veterinary Medicine, Institutional Animal Care and Use Committee (IACUC), University of Nigeria, Nsukka (FVM No.20/20/11/7). The rats were randomly (randomized controlled trial) divided into four groups of eight rats each. Group A was administered $0.5 \mathrm{ml}$ of $2 \%$ tween 80 in distilled water orally and a single subcutaneous dose of phosphate buffered saline (PBS); Group B was administered a single subcutaneous (SC) dose of cadmium at $3 \mathrm{mg} / \mathrm{kg}$ in PBS only; Group C was administered $500 \mathrm{mg} / \mathrm{kg}$ TVE in $2 \%$ tween 80 in distilled water orally, daily for 3 weeks while Group D was administered single (SC) dose of cadmium (SC) at $3 \mathrm{mg} /$ $\mathrm{kg}+500 \mathrm{mg} / \mathrm{kg}$ TVE in $2 \%$ tween 80 in distilled water orally, daily for 3 weeks. The group allocation and treatment were concealed from the laboratory technologist and pathologist involved in sample analysis and interpretation. The effective dose of $\mathrm{Cd}$ and the extract used and the duration of study were based on previous reports (Ponnusamy and Pari 2011; Onoja et al. 2020).

\section{Sample collection}

At the end of the experiment, the rats were fasted overnight and $2 \mathrm{~mL}$ of blood was collected via the retroorbital plexus into plain sample bottles after euthanasia by intraperitoneal injection of $90 \mathrm{mg} / \mathrm{kg}$ body weight ketamine hydrochloride and $5 \mathrm{mg} / \mathrm{kg}$ body weight xylazine (Zarei and Shahrooz 2019). Blood in the plain sample bottles was allowed to clot, centrifuged $(3000 \mathrm{rpm}$ 
for $10 \mathrm{~min}$ ) and serum was collected for hormonal assay. Thereafter, the rats were dissected and the epididymis was collected for sperm count while the testes were harvested for antioxidant enzyme activity, lipid peroxidation assay and histopathology.

\section{Spermatogenic activity}

The testicular and epididymal weights were determined using a sensitive Mettler weighing balance (manufactured by Mettler Toledo, Switzerland) while the epididymal sperm count was assessed using the standard haemocytometric method (Obembe and Ige 2016).

\section{Hormonal assay}

Enzyme-linked immuno-absorbent assay (ELISA) kit was used for the quantitative determination of testosterone, luteinizing hormone (LH) and follicle stimulating hormone (FSH) concentration according to the manufacturer's protocols.

\section{Lipid peroxidation and antioxidant assay}

Lipid peroxidation biomarker, malondyaldehyde (MDA) was measured by spectrophotometric method as described previously (Ohkawa et al. 1979), while catalase (CAT) and superoxide dismutase (SOD) activity was estimated according to standard methods (Nishikimi et al. 1972; Hadwan 2018).

\section{Histopathological evaluation}

Testes from the different groups were dehydrated in graded concentrations of ethanol, cleared in xylene, and embedded in paraffin wax. Five-micrometer thick sections were cut, mounted on glass slides, and stained with haematoxylin and eosin for light microscopy (Bancroft and Gamble 2008).

\section{Statistical analysis}

Statistical analyses of data were carried out by one way analysis of variance (ANOVA) using the Statistical Package for Social Sciences (SPSS) version 22.0. The mean differences were considered significant at $p \leq 0.05$.

\section{Results}

Body, testicular and epididymal weights

Table 1 shows the body weights, testicular and epididymal weights of rats. Compared with control, there was no significant difference in body weight between the $\mathrm{CdCl}_{2}$-treated rats and control group. It was observed that $\mathrm{CdCl}_{2}$-treated rats showed a significant decrease in testes and epididymal weights when compared with the control group. However, the testis and epididymal weights of rats administered $\mathrm{CdCl}_{2}$ and treated with TVE were not significantly $(p \geq 0.05)$ different compared to the control.

\section{Epididymal sperm counts}

The epididymal sperm counts were significantly $(p \leq 0.05)$ lower in the $\mathrm{CdCl}_{2}$-treated group compared to the control (Fig. 1). Although, the $\mathrm{CdCl}_{2}+\mathrm{TVE}$ group showed an increase in sperm count, this was not significantly $(p \geq 0.05)$ different from the $\mathrm{CdCl}_{2}$-treated group.

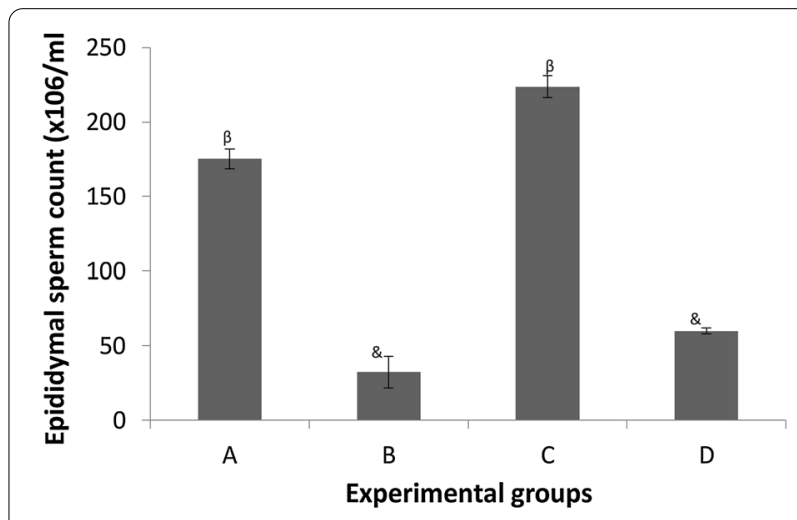

Fig. 1 A graph showing the mean epididymal sperm counts of rats from the experimental Group A (control), Group B (3 mg/kg CdCl $)$, Group C (500 mg/kg TVE) and Group D (3 mg/kg CdCl $2+500 \mathrm{mg} /$ $\mathrm{kg}$ TVE). The values are expressed as mean \pm S.E.M $(n=8)$. The level of significance was set at $p \leq 0.05$. Bars with different superscripts are significantly different

Table 1 Effects of Thymus vulgaris extract on body weight, testicular and epididymal weights of rats

\begin{tabular}{lcrrr}
\hline Parameters & A (Control) & B (CdCl $)$ & C (TVE only) & D (CdCl + TVE) \\
\hline Body weight (g) & $193.50 \pm 6.68^{\mathrm{a}}$ & $185.60 \pm 9.97^{\mathrm{a}}$ & $191.50 \pm 8.88^{\mathrm{a}}$ & $189.50 \pm 5.41^{\mathrm{a}}$ \\
Testicular weight (g) & $2.83 \pm 0.12^{\mathrm{a}}$ & $1.57 \pm 0.47^{\mathrm{b}}$ & $3.83 \pm 0.39^{\mathrm{a}}$ & $1.77 \pm 0.09^{\mathrm{b}}$ \\
Testicular/BW ratio (\%) & $1.45 \pm 0.01^{\mathrm{a}}$ & $0.83 \pm 0.03^{\mathrm{b}}$ & $1.98 \pm 0.08^{\mathrm{a}}$ & $0.92 \pm 0.08^{\mathrm{b}}$ \\
Epididymal weight (g) & $0.87 \pm 0.19^{\mathrm{a}}$ & $0.53 \pm 0.03^{\mathrm{b}}$ & $1.63 \pm 0.38^{\mathrm{a}}$ & $0.65 \pm 0.13^{\mathrm{b}}$ \\
Epididymal/BW ratio (\%) & $0.42 \pm 0.15^{\mathrm{a}}$ & $0.25 \pm 0.05^{\mathrm{b}}$ & $0.83 \pm 0.14^{\mathrm{a}}$ & $0.32 \pm 0.03^{\mathrm{b}}$ \\
\hline
\end{tabular}

Values are Mean \pm S.E.M, $n=8$; BW, body weight; $\mathrm{g}$, gram; $\mathrm{CdCl}_{2}$, Cadmium chloride; TVE, Thymus vulgaris extract. Mean values bearing different superscripts in the same row differ significantly at $p \leq 0.05$ 
Table 2 Serum concentration of reproductive hormones of the experimental groups of rats

\begin{tabular}{llll}
\hline Groups & FSH (ng/dl) & LH(ng/dl) & Testosterone(ng/dl) \\
\hline A (Control) & $2.77 \pm 0.15^{\mathrm{a}}$ & $0.35 \pm 0.05^{\mathrm{a}}$ & $5.47 \pm 0.48^{\mathrm{a}}$ \\
$\mathrm{B}\left(\mathrm{CdCl}_{2}\right)$ & $0.70 \pm 0.21^{\mathrm{b}}$ & $0.19 \pm 0.02^{\mathrm{b}}$ & $2.13 \pm 0.18^{\mathrm{b}}$ \\
$\mathrm{C}\left(\mathrm{TVE}_{\mathrm{only}}\right)$ & $3.03 \pm 0.20^{\mathrm{a}}$ & $0.34 \pm 0.03^{\mathrm{a}}$ & $4.77 \pm 0.43^{\mathrm{a}}$ \\
$\mathrm{D}\left(\mathrm{CdCl}_{2}+\mathrm{TVE}\right)$ & $1.03 \pm 0.29^{\mathrm{b}}$ & $0.16 \pm 0.03^{\mathrm{b}}$ & $2.77 \pm 0.20^{\mathrm{b}}$ \\
\hline
\end{tabular}

Values are Mean \pm S.E.M, $n=8 ; n g / d l$, nanogram per decilitre; TVE, Thymus vulgaris extract; $\mathrm{CdCl}_{2}$, Cadmium chloride; $\mathrm{LH}$, luteinizing hormone; $\mathrm{FSH}$, follicle stimulating hormone. Mean values bearing different superscripts in the same column differ significantly at $p \leq 0.05$

Table 3 Effect of Thymus vulgaris extract testicular oxidative stress marker and antioxidant enzyme activity of the experimental groups of rats

\begin{tabular}{|c|c|c|c|}
\hline Groups & $\begin{array}{l}\text { MDA(nmol/g } \\
\text { tissue) }\end{array}$ & $\begin{array}{l}\text { SOD }((U / g \\
\text { tissue) }\end{array}$ & CAT(U/g tissue) \\
\hline A (Control) & $36.40 \pm 1.04^{a}$ & $41.80 \pm 1.28^{\mathrm{a}}$ & $34.57 \pm 1.04^{\mathrm{a}}$ \\
\hline $\mathrm{B}\left(\mathrm{CdCl}_{2}\right)$ & $103.70 \pm 3.42^{b}$ & $16.87 \pm 1.01^{b}$ & $18.80 \pm 0.81^{b}$ \\
\hline C (TVE only) & $27.17 \pm 6.18^{a}$ & $42.80 \pm 2.87^{\mathrm{a}}$ & $44.00 \pm 2.60^{c}$ \\
\hline $\mathrm{D}\left(\mathrm{CdCl}_{2}+\mathrm{TVE}\right)$ & $88.50 \pm 5.39^{c}$ & $22.30 \pm 0.91^{b}$ & $24.80 \pm 0.78^{d}$ \\
\hline
\end{tabular}

Values are Mean \pm S.E.M, $n=8 ; n$ mol $/ \mathrm{g}$, nanomoles per gram; $\mathrm{U} / \mathrm{g}$, units per gram; TVE, Thymus vulgaris extract; $\mathrm{CdCl}_{2}$, Cadmium chloride; MDA, malondyaldehyde; CAT, catalase; SOD, superoxide dismutase. Mean values bearing different superscripts in the same column differ significantly at $p \leq 0.05$

\section{Serum testosterone, $\mathrm{LH}$ and $\mathrm{FSH}$}

The hormonal profile in the experimental groups showed a significantly $(p \leq 0.05)$ lower serum FSH, LH and testosterone in $\mathrm{CdCl}_{2}$-treated rats when compared to the control (Table 2). However, the serum FSH, LH and testosterone levels in the rats administered $\mathrm{CdCl}_{2}$ and treated with TVE were comparable to the group administered $\mathrm{CdCl}_{2}$ only.

\section{Testicular oxidative stress and antioxidant markers}

The administration of $\mathrm{Cd}$ to rats in group B led to a significant $(p \leq 0.05)$ decrease in SOD and CAT activity with increased MDA concentration in the testis compared to the control group A and TVE treated group C. However, the co-administration of $\mathrm{Cd}$ and TVE in group $\mathrm{D}$ increased activity of CAT and SOD with a significant decrease in the MDA level in testicular tissues when compared to group B (Cd only) as shown in Table 3.

\section{Histopathology}

Histopathological evaluation (Fig. 2) revealed normal seminiferous tubular epithelium with spermatogenic cell lines and lumen filled with numerous spermatids in the control group. The $\mathrm{CdCl}_{2}$-treated group showed severe testicular damage which included degeneration, coagulative necrosis of seminiferous tubular epithelium with increased interstitial space, mononuclear cells infiltration and Sertoli cells-only pattern of tubules, while rats administered $\mathrm{Cd}$ and treated with TVE had mild restoration in testicular architecture.

\section{Discussion}

Human exposure to $\mathrm{CdCl}_{2}$ usually occurs through occupational contact in factories and consumptions of contaminated food and drinking water (El-Demerdash et al. 2004; de Souza et al. 2010). Cd can cause blood-testis barrier disruption, germ cell loss, testicular oedema, haemorrhage and necrosis leading to impaired reproductive physiology and irreversible infertility (Zikic et al.1998; Takiguchi and Yoshihara 2006; Blanco et al. 2007; Acharya et al. 2008; Deng et al. 2010; Oguzturk et al. 2012). As seen in the present study, the testicular and epididymal weights were decreased in the $\mathrm{CdCl}_{2}$-treated group compared to the control. It is well known that the weight of the testis depends on the mass of undifferentiated spermatogenic cells (Ponnusamy and Pari 2011) and can also serve as the primary indicator of a possible alteration in androgen status (Biswas et al. 2001). This was observed in the serum FSH, LH and testosterone levels in $\mathrm{CdCl}_{2}$-treated group which showed a substantial decrease when compared to the control. $\mathrm{Cd}$ exerts its known toxic effects on organs of the body like the testis through its induction of oxidative stress (Dzobo and Naik 2013; Kumar et al. 2019).

In experimental models, $\mathrm{Cd}$ exposure is known to affect testis weight and induce pathology leading to reduced sperm count which adversely affects male fertility (Biswas et al. 2001; Yang et al. 2006). This was also confirmed by the severe necrosis of the seminiferous tubules and interstitial inflammation of the testis, as seen in the $\mathrm{CdCl}_{2}$-group. This study also showed that administration of TVE did not elicit meaningful amelioration of cadmium-induced testicular damage. However, the consistent tendencies for increase in testicular and epididymal weights, epididymal sperm counts, serum FSH and testosterone, and mild reduction in the severity of interstitial inflammation in the group that was administered $\mathrm{CdCl}_{2}$ and treated with TVE is promising. Hence, it can be stated that at higher doses and/or longer duration of study, TVE can reverse or ameliorate the testicular toxicity induced by $\mathrm{Cd}$ which is in contrast with previous studies (El-Newary et al. 2017; Onoja et al. 2020) where TVE was shown to protect against hepatotoxicity induced by $\mathrm{Cd}$. The discrepancies were partly, attributed to differences in sensitivity of the organs to TVE. However, the antioxidant enzyme activity in the testes of rats administered $\mathrm{CdCl}_{2}$ and treated with TVE increased but was relatively lower compared to those reported in the 

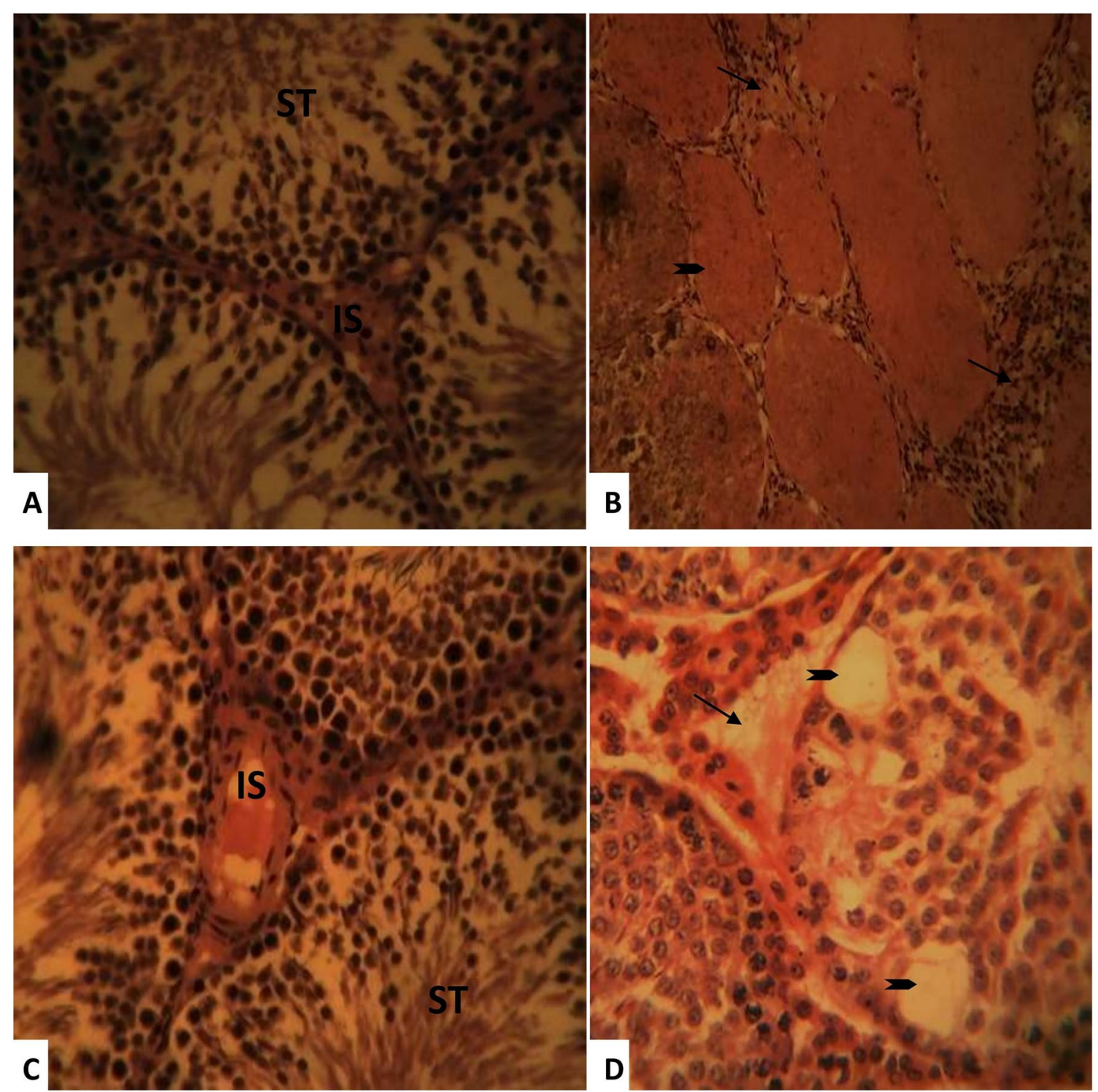

Fig. 2 Photomicrograph of the testis from Group A (control) rats showing normal seminiferous tubules (ST) and interstitial space (IS). Group B ( $3 \mathrm{mg} / \mathrm{kg} \mathrm{CdCl}$ ) rats showing severe necrosis of seminiferous tubules (arrowheads) and interstitial inflammation (thin arrows); Group C (500 mg/ $\mathrm{kg}$ TVE) rats showing normal seminiferous tubules (ST) and interstitial space (IS) and Group D (3 mg/kg CdCl $+500 \mathrm{mg} / \mathrm{kg}$ TVE) rats showing a preserved testicular histoarchitecture with mild vacuolation and necrosis of seminiferous tubules (arrowheads) and interstitial oedema (thin arrows). $H \& E_{1} 400 \times$

aforementioned studies. This may further account for the observed low potency of TVE on cadmium-induced testicular injury.

\section{Conclusion}

This study shows that Thymus vulgaris leaf extract has weak ameliorative effect on cadmium- induced testicular damage in rats and also high antioxidant activity.

\section{Abbreviations}

ARRIVE: Animal Research Reporting of In Vivo Experiments; TVE: Thymus vulgaris Extract; Cd: Cadmium; SC: Subcutaneous; PBS: Phosphate buffered saline; $\mathrm{CdCl}_{2}$ : Cadmium chloride; LD50: Lethal dose 50; LH: Luteinizing hormone; FSH: Follicle stimulating hormone; MDA: Malondialdehyde; CAT: Catalase; SOD:

Superoxide dismutase; BW: Body weight.

\section{Acknowledgements}

The assistance of the technical staff of the Department of Veterinary Pathology and Microbiology, Faculty of Veterinary Medicine, University of Nigeria, Nsukka, is appreciated.

\section{Licence/permission}

Not applicable. 


\section{Authors' contributions}

$\mathrm{RIO}$ and CUC were involved in research conceptualization, supervision and writing of the original draft. WO was involved in research conceptualization, interpretation of toxicological data and proof reading of the manuscript. EUU, DCA and BIE were involved in data collection and analysis. All authors read and approved the final manuscript.

\section{Funding}

No funding was obtained for this study.

\section{Availability of data and materials}

All data analysed and generated in this study are mentioned in this article.

\section{Declarations}

\section{Ethics approval and consent to participate}

This study was approved by the Faculty of Veterinary Medicine Institutional Animal Care and Use Committee University of Nigeria, Nsukka (FVM2020117) in compliance with ARRIVE guidelines.

\section{Consent for publication}

Not applicable.

\section{Competing interests}

The authors declare that they have no competing interests.

\section{Author details}

${ }^{1}$ Department of Veterinary Pathology and Microbiology, Faculty of Veterinary Medicine, University of Nigeria, Nsukka 410001, Nigeria. ${ }^{2}$ Department of Biochemistry, School of Life Sciences, Modibbo Adama University of Technology Yola, Yola, Nigeria. ${ }^{3}$ Institute for Drug Herbal Medicine Excipients Research and Development, Department Of Pharmaceutical Microbiology and Biotechnology, Faculty of Pharmaceutical Sciences, University of Nigeria, Nsukka, Nigeria.

\section{Received: 12 April 2021 Accepted: 6 July 2021}

Published online: 13 July 2021

\section{References}

Acharya UR, Mishra M, Patro J, Panda MK (2008) Effect of vitamins C and E on spermatogenesis in mice exposed to cadmium. Reprod Toxicol 25:84-88. https://doi.org/10.1016/j.reprotox.2007.10.004

Bagchi D, Vuchetich PJ, Bagchi M, Hassoun EA, Tran MX, Tang L, Stohs SJ (1997) Induction of oxidative stress by chronic administration of sodium dichromate (chromium VI) and cadmium chloride (cadmium II) to rats. Free Rad Biol Med 22:471-478. https://doi.org/10.1016/s0891-5849(96)00352-8

Bancroft JD, Gamble M (2008) Theory and practice of histological techniques, 6th edn. Churchill Livingstone, London, pp 273-292

Biswas NM, Sen Gupta R, Chattopadhyay A, Choudhury GR, Sarkar M (2001) Effect of atenolol on cadmium-induced testicular toxicity in male rats. Reprod Toxicol 15(6):699-704. https://doi.org/10.1016/s0890-6238(01) 00184-8

Blanco A, Moyano R, Vivo J, Flores-Acuña R, Molina A, Blanco C, Agüera E, Monterde JG (2007) Quantitative changes in the testicular structure in mice exposed to low doses of cadmium. Environ Toxicol Pharmacol 23(1):96-101. https://doi.org/10.1016/j.etap.2006.07.008

Chaves N, Santiago A, Alias JC (2020) Quantification of the antioxidant activity of plant extracts, analysis of sensitivity and hierarchization based on the method used. Antioxidants (basel) 9(1):76. https://doi.org/10.3390/antio x9010076

Daud D, Fekery NFM, Hashim N (2017) Reproductive health of rats with benign prostatic hyperplasia following Cosmos caudatus ethanolic extracts consumption. J App Pharm Sci 7(6):202-205. https://doi.org/10.7324/ japs.2017.70630

de Souza PF, Diamante MA, Dolder H (2010) Testis response to low doses of cadmium in Wistar rats. Int J Exp Pathol 91:125-131. https://doi.org/10. 1111/j.1365-2613.2009.00692.x
Deng X, Xia Y, Hu W, Zhang H, Shen Z (2010) Cadmium-induced oxidative damage and protective effects of $\mathrm{N}$-acetyl-L-cysteine against cadmium toxicity in Solanum nigrum L. J Hazard Mater 180:722-729. https://doi. org/10.1016/j.jhazmat.2010.04.099

Dzobo K, Naik YS (2013) Effect of selenium on cadmium-induced oxidative stress and esterase activity in rat organs. S Afr J Sci 109(5-6):1-8. https:// doi.org/10.1590/sajs.2013/965

El-Demerdash FM, Yousef MI, Kedwany FS, Baghdadi HH (2004) Cadmiuminduced changes in lipid peroxidation, blood hematology, biochemical parameters and semen quality of male rats: protective role of vitamin $\mathrm{E}$ and beta-carotene. Food Chem Toxicol 42:1563-1571. https://doi.org/10. 1016/j.fct.2004.05.001

El-Nekeety AA, Mohamed SR, Hathout AS, Hassan NS, Aly SE, Abdel-Wahhab MA (2011) Antioxidant properties of Thymus vulgaris oil against aflatoxininduce oxidative stress in male rats. Toxicon 57(7-8):984-991. https://doi. org/10.1016/j.toxicon.2011.03.021

El-Newary SA, Shaffie NM, Omer EA (2017) The protection of Thymus vulgaris leaves alcoholic extract against hepatotoxicity of alcohol in rats. Asian Pac J Trop Med 4:361-371. https://doi.org/10.1016/j.apjtm.2017.03.023

Gouthamchandra K, Mahmood R, Manjunatha H (2010) Free radical scavenging, antioxidant enzymes and wound healing activities of leaves extracts from Clerodendrum infortunatum L. EnvironToxicol Pharmacol 30:11-18. https://doi.org/10.1016/j.etap.2010.03.005

Hadwan MH (2018) Simple spectrophotometric assay for measuring catalase activity in biological tissues. BMC Biochem 19(1):7. https://doi.org/10. 1186/s12858-018-0097-5

Kumar A, Pandey R, Siddiqi NJ, Sharma B (2019) Oxidative stress biomarkers of cadmium toxicity in mammalian systems and their distinct ameliorative strategy. J Appl Biotechnol Bioeng 6(3):126-135

Miliauskas G, Venskutonis PR, van Beek TA (2004) Screening of radical scavenging activity of some medicinal and aromatic plant extracts. Food Chem 85:231-237. https://doi.org/10.1016/j.foodchem.2003.05.007

National Research Council (2011) Committee for the update of the guide for the care and use of laboratory animals, guide for the care and use of laboratory animals, 8th edn. National Academies Press, Washington, DC

Nishikimi M, Appaji N, Yagi K (1972) The occurrence of superoxide anion in the reaction of reduced phenazine methosulfate and molecular oxygen. Biochem Biophys Res Commun 46(2):849-854. https://doi.org/10.1016/ S0006-291X(72)80218-3

Obembe OO, Ige AO (2016) Sperm parameters of male Wistar rats treated with Anacardium occidentale L. leaf extract. Res J Health Sci 4(1):83-89

OECD Test No 423 (2003) Acute oral toxicity-acute toxic class method. Organization for Economic Cooperation and Development Guidelines for the Testing of Chemicals, Section 4, OECD Publishing, Paris

Ognjanović BI, Marković SD, Ethordević NZ, Trbojević IS, Stajn AS, Saicić ZS (2010) Cadmium-induced lipid peroxidation and changes in antioxidant defense system in the rat testes: protective role of coenzyme Q(10) and vitamin E. Reprod Toxicol 29:191-197. https://doi.org/10.1016/j.reprotox. 2009.11.009

Oguzturk H, Ciftci O, Aydin M, Timurkaan N, Beytur A, Yilmaz F (2012) Ameliorative effects of curcumin against acute cadmium toxicity on male reproductive system in rats. Andrologia 44(4):243-249. https://doi.org/10. 1111/j.1439-0272.2012.01273.x

Ohkawa H, Ohishi N, Yagi K (1979) Assay for lipid peroxides in animal tissues by thiobarbituric acid reaction. Anal Biochem 95(2):351-358. https://doi.org/ 10.1016/0003-2697(79)90738-3

Ola-Mudathir KF, Suru SM, Fafunso MA, Obioha UE, Faremi TY (2008) Protective roles of onion and garlic extracts on cadmium-induced changes in sperm characteristics and testicular oxidative damage in rats. Food Chem Toxicol 46:3604-3611. https://doi.org/10.1016/j.fct.2008.09.004

Onoja RI, Chukwudi CU, Emejuo NT, Ugwuanyi HE, Ugwueze EU (2020) Possible ameliorative effects of hydromethanol extract of Thymus vulgaris on cadmium-induced hepato-renal toxicity in rats. Not Sci Biol 12(3):568577. https://doi.org/10.15835/nsb12310765

Ponnusamy M, Pari L (2011) Protective role of diallyl tetrasulfide on cadmiuminduced testicular damage in adult rats: a biochemical and histological study. Toxicol Ind Health 27(5):407-416. https://doi.org/10.1177/07482 33710387633

Rustaiyan A, Masoudi S, Monfared A, Kamalinejad M, Lajevardi T, Sedaghat S, Yari M (2000) Volatile constituents of three Thymus species grown wild in Iran. Planta Med 66(2):197-198. https://doi.org/10.1055/s-0029-1243136 
Satyal P, Murray BL, McFeeters RL, Setzer WN (2016) Essential oil characterization of Thymus vulgaris from various geographical locations. Foods 5(4):70. https://doi.org/10.3390/foods5040070

Siu ER, Mruk DD, Porto CS, Yan Cheng C (2009) Cadmium-induced testicular injury. Toxicol Appl Pharmacol 3:240-249. https://doi.org/10.1016/j.taap. 2009.01.028

Takiguchi M, Yoshihara S (2006) New aspects of cadmium as endocrine disruptor. Environ Sci 13(2):107-116

Thompson J, Bannigan J (2008) Cadmium: toxic effects on the reproductive system and the embryo. Reprod Toxicol 25:304-315. https://doi.org/10. 1016/j.reprotox.2008.02.001

Tremellen K (2008) Oxidative stress and male infertility-a clinical perspective. Hum Reprod Update 4:243-258. https://doi.org/10.1093/humupd/ dmn004

Turner TT, Lysiak JJ (2008) Oxidative stress: a common factor in testicular dysfunction. J Androl 29:488-498. https://doi.org/10.2164/jandrol.108. 005132

Vigo E, Cepeda A, Gualillo O, Perez-Fernandez R (2004) In vitro anti-inflammatory effect of Eucalyptus globulus and Thymus vulgaris: nitric oxide inhibition in J774A.1 murine macrophage. J Pharm Pharmacol 56(2):257-263. https://doi.org/10.1211/0022357022665
WHO (1999) WHO monographs on selected medicinal plants, vol.1. World Health Organization, Geneva

Yang HS, Han DK, Kim JR, Sim JC (2006) Effects of alpha-tocopherol on cadmium-induced toxicity in rat testis and spermatogenesis. J Korean Med Sci 21(3):445-451. https://doi.org/10.3346/jkms.2006.21.3.445

Zarei L, Shahrooz R (2019) Protective effects of Cornus mas fruit extract on methotrexate-induced alterations in mice testicular tissue: evidences for histochemical and histomorphometrical changes in an animal model study. Vet Res Forum 10(4):307-313. https://doi.org/10.30466/vrf.2019. 69516.1955

Zikic RV, Stajn AS, Ognjanovic BI, Saicic ZS, Kostic MM, Pavlovic SZ, Petrovic VM (1998) The effect of cadmium and selenium on the antioxidant enzyme activities in rat heart. J Environ Pathol Toxicol Oncol 1:259-264

\section{Publisher's Note}

Springer Nature remains neutral with regard to jurisdictional claims in published maps and institutional affiliations.

\section{Submit your manuscript to a SpringerOpen ${ }^{\circ}$ journal and benefit from:}

- Convenient online submission

- Rigorous peer review

- Open access: articles freely available online

- High visibility within the field

- Retaining the copyright to your article

Submit your next manuscript at $\boldsymbol{\nabla}$ springeropen.com 